\title{
Notes on the metal pyxides \\ recently discovered in the Sarmatian environment south the Lower Mureș River
}

\section{Vitalie Bârcă (Romania)}

\begin{abstract}
This study, although not exhaustive, attempts to analyse pieces of the type discovered in the Sarmatian environment of the Great Hungarian Plain starting from the bronze and iron pyxides discovered in 2010 during the rescue archaeological excavations prior the construction of the Arad-Timişoara Motorway, namely, sector Arad-Seceani, in graves 3 and 7 from the cemetery investigated at Hunedoara Timişană, Şagu commune, Arad county. The author discusses the pieces from Hunedoara Timişană, together with pieces recovered from other funerary complexes of the Great Hungarian Plain, in a broader context and concludes that the graves where they were identified are women and children graves.
\end{abstract}

The pyxides from G 3 at Hunedoara Timişană, together with the rest of the grave goods, but also with those of the surrounding graves, support a dating most likely to the second-third/mid-third quarter of the 3rd century AD. The specimen in G 7 was interpreted as having been used as a rattle (Pyxidenklapper), thus rather fulfilling the function of a pendant, the grave dating sometime to the chronological interval between the end of the 2 nd - 3rd quarter of the 3rd century $\mathrm{AD}$.

Upon the analysis of such metal pieces recovered in the Sarmatian environment, the author notes that they are not often recorded in the Sarmatian cemeteries of the Great Hungarian Plain and that their diffusion area lies mainly in the Tisza river basin, being also represented in the territory between the Lower Mureş, Tisza and Danube.

Based on their manufacture, together with their decoration and its execution, the author concludes that the bronze pyxides from G 3 at Hunedoara Timişană likely are artifacts made by a Roman artisan, possibly travelling, active in the area of economic interaction near the Roman limes.

Finally, the author concludes that metal pyxides from the Sarmatian environment of the Great Hungarian Plain, like the rest of the eastern Sarmatian world, include containers for both cosmetic products as well as for a variety of medicinal herbs.

Keywords: pyxides, graves, the Sarmatians, the Iazyges, the Great Hungarian Plain, Banat, the Barbaricum. 
Pyxides are toiletry items that were very popular in the Roman period. They are lidded and occasionally provided with mechanisms for fastening to or hanging from the belt or braid. They served mainly for keeping face and body paints, substances used in makeup or aromatic substances, and rarely, mineral materials, resins or herbs deemed healing. The remains of the latter are frequently found inside the pyxides. They were made of bone, wood and metal (silver, bronze), some having their surface decorated.

In the Sarmatian graves from the eastern territories, this class of objects is mainly represented by specimens made of bone and wood. Such pieces are frequent in the Sarmatian graves from the both the north and north-west Pontic area as well as in those east of the Don (Vyaz'mitina 1954, 240, Pl. V/10; Melyukova 1962, 205; Arkheologiya Ukrainskoj SSR 1986, II, 212-213; Arkheologiya SSSR 1989, 188, Pl. 80/14, 21; Simonenko 1981, 63, Fig. 4/9-10; Kovpanenko 1986, 78-80, Fig. 82-83; Bespalyj 1992, 177, Fig. 1/6; Kostenko 1983, Fig. 12/39; Kostenko 1993, 49, 109, Fig. 16/32; Gushchina, Zasetskaya 1994, cat. no. 115, 127, 132, 300, 322, Pl. 12/115, 13/127, 132, 32/300, 34/322; Trejster 1994, 179, Fig. 4; Bârcă 2006, 161, Fig. 7/3-5, 17/5, 51/1; Bârcă, Symonenko 2009, 178, Fig. 64/1-3, 8; Mordvintseva, Trejster 2007, I, 55, II, 41, cat. nr. A114.4, III, Pl. 30/A114.4;. Simonenko 2008, 30, Pl. 26/1, 48/2b, 80/1, 107/3, 136/4, 137/3, 139/2a, 141/1e; Simonenko 2011, 109111, Fig. 67; Marčenko, Limberis 2008, 309, Pl. 2/2, 68/7, 69/8, 78/2, 81/3, 110/1.). They are also present in the North-Pontic Greek cities (Sokol'skii 1971, 205, 206, 209, 210, 214, 215, Pl. X/1, XXIX/8, 10, 14, 15, XXX/6; Kovpanenko 1986, 80 with bibliography.), the late Scythian environment of the Crimea (Puzdrovskij 2007, 155-156, Fig. 133/12-15, 135/1-8, 136/1-2, 6-7.), Maeotian (Marčenko, Limberis 2008, 309, Pl. 185/3, 190/2) and also in the Roman provinces (Petru 1972, Pl. LXIV/4, LXVIII/24, XCV/13; Bíró 1994, 97, 127, Pl. LI-LII; Béal, Feugère 1983). Nor are they are not missing from the Sarmatian environment of the Great Hungarian Plain, including the area between the Lower Mureş, Tisza and Danube, where they have been recently discovered in G 3 and G 7 in the Sarmatian cemetery at Hunedoara Timişană, Şagu commune, Arad county, Romania (Fig. 1).

The cemetery where the pyxides were found was identified in the summer of 2010 during the rescue archaeological excavations carried out before the construction of the Arad-Timişoara motorway, namely in the Arad-Seceani sector (Cf. Bârcă et alii 2011, 187-192). The investigations revealed and examined $\mathbf{1 7}$ inhumations to which are also added the specimens recovered from a grave damaged in the construction of an early medieval house (for more details and information related to this cemetery see Bârcă 2014). 


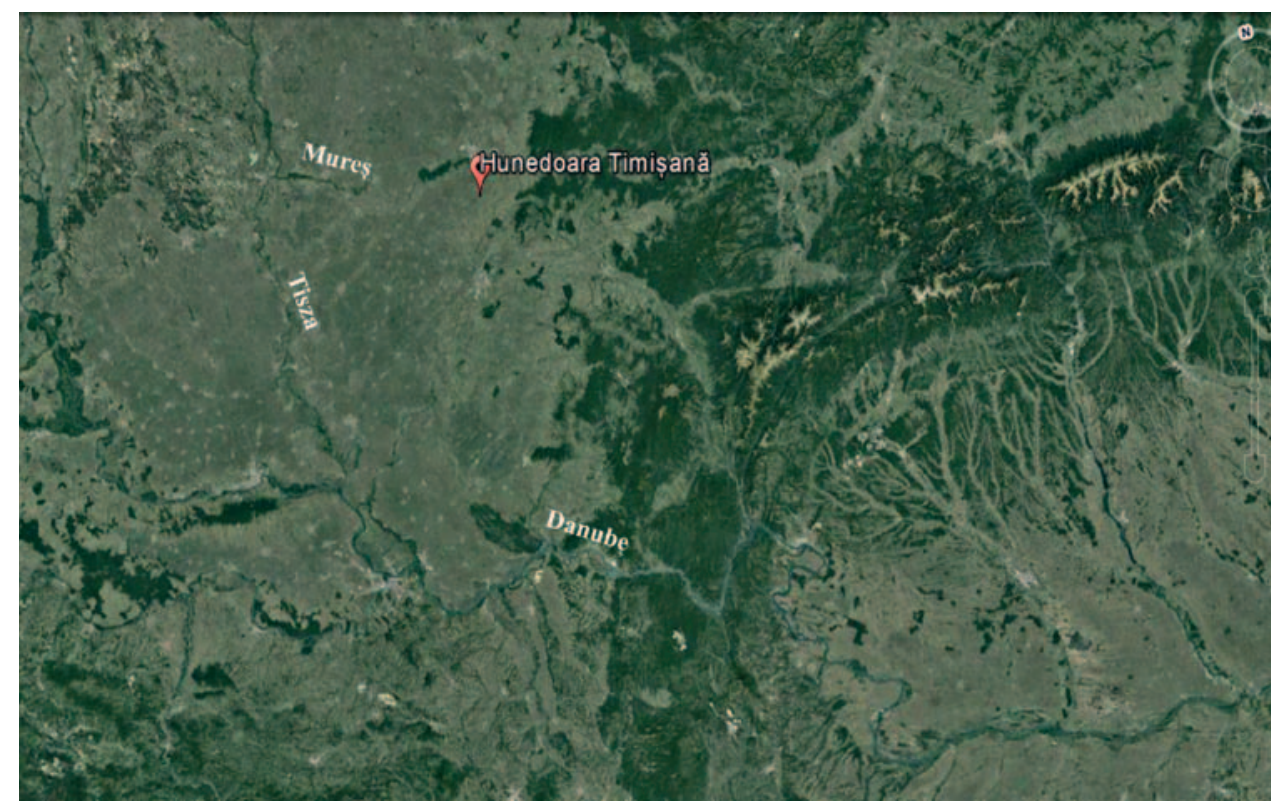

Fig. 1. Location of the cemetery at Hunedoara Timișană.

Grave pit 3 (G 3), rectangular with rounded corners, was oriented NWSE. Along the long sides and the short northern side, the grave pit was stepped. The pit proper, in which the deceased was placed, was rectangular with rounded corners (Fig. 2; 9/1). Wooden traces and remains discovered in lower part of the pit filling, beside fragmentary iron clasps (Fig. 2), record a lidded coffin (for Sarmatian burials in coffins and wooden funerary furnishings recently discovered in the Western Plain of Romania see Bârcă, Grumeza 2014, 157-194).

The deceased, a woman aged 17-25 years, was lying on her back, head to the SE. The skull was leaning on the left shoulder, arms along the body and legs stretched. Forearms and the bones of both palm did not survive, nor did those of both feet (Fig. 2; 9/1).

The richly furnished grave contained two silver earrings made of a single metal wire, with one end bent in the shape of a hook, the other bent in the shape of a small loop wrapped around the body, 520 complete beads and a few dozen small fragments, a fragmentary iron ring and the fragments of one glass vessel (for more information see Bârcă 2014). To these are added the fragments of a bronze brooch, of which the bilateral spring made up of 8 coils attached to a rectangular support, the pin and the rectangular catch plate survive. Both the support and catch plate were attached to a geometric body. These pieces are completed by the disc box-shaped brooch made of a silver-based alloy (Cf. Fig. 2-5; 9). 


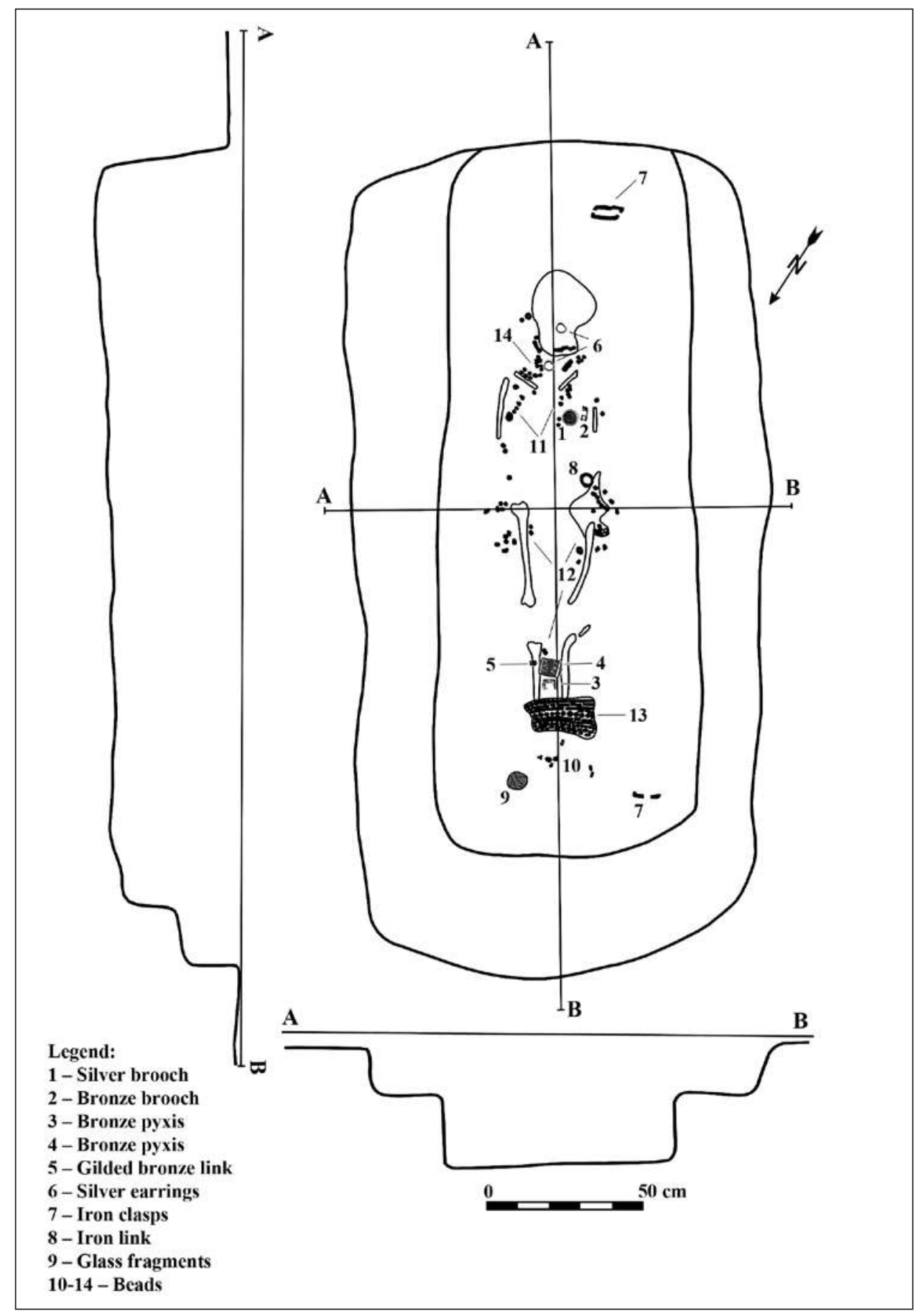

Fig. 2. Grave 3 at Hunedoara Timișană. Legend: 1. Silver brooch; 2. Bronze brooch; 3. Bronze pyxis; 4. Bronze pyxis; 5. Gilt bronze link; 6. Silver earrings; 7. Iron clasps; 8. Iron link; 9. Glass fragments; 10-14. Beads. 


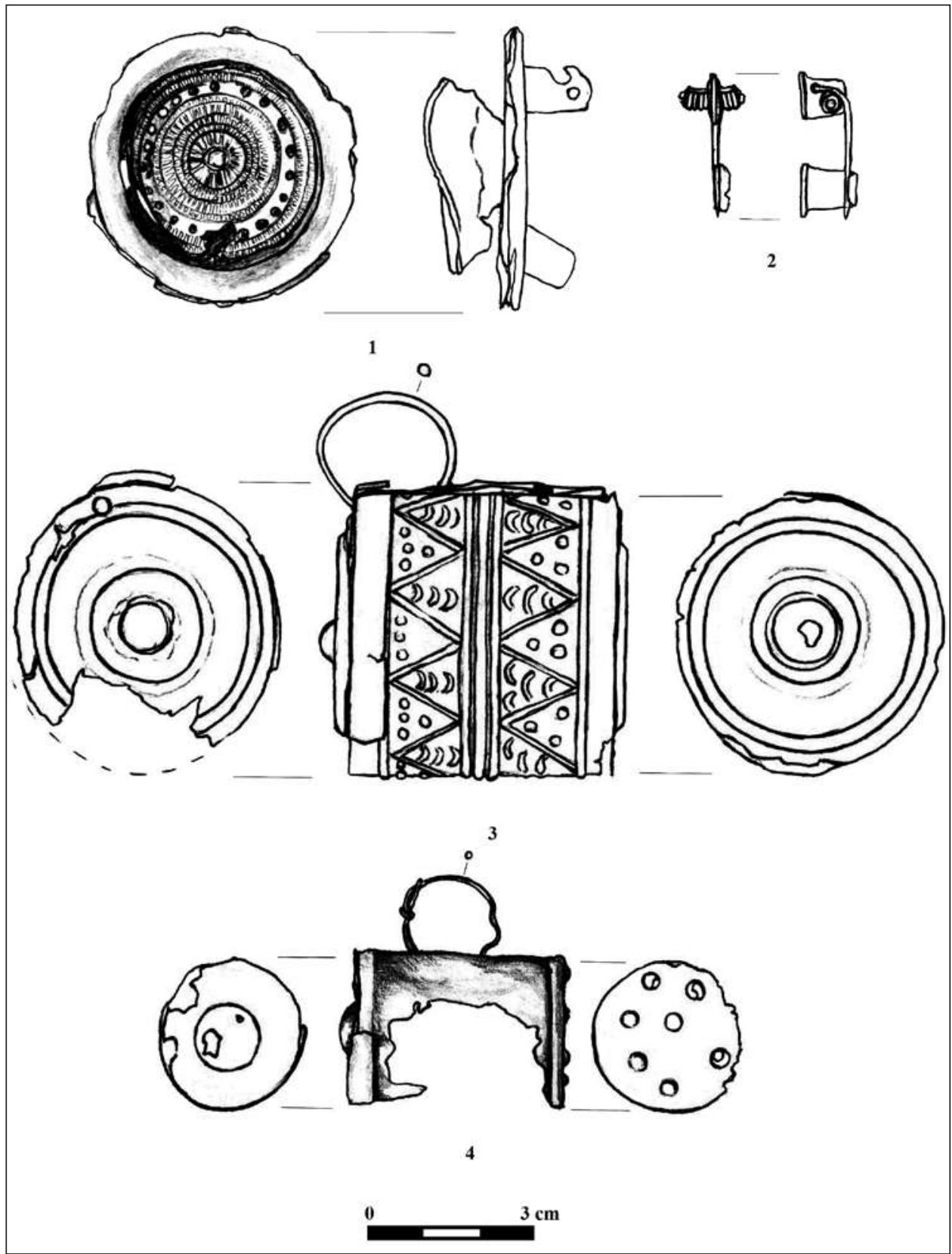

Fig. 3. Objects belonging to the inventory of grave 3 at Hunedoara Timișană. 1. Silver brooch; 2. Bronze brooch; 3-4. Bronze pyxides.

The rich furnishings of grave G 3, as well as a series of funerary ritual elements, date it to sometime in the second-third/mid-third quarter of the 3rd century AD (for more information see Bârcă 2014). 


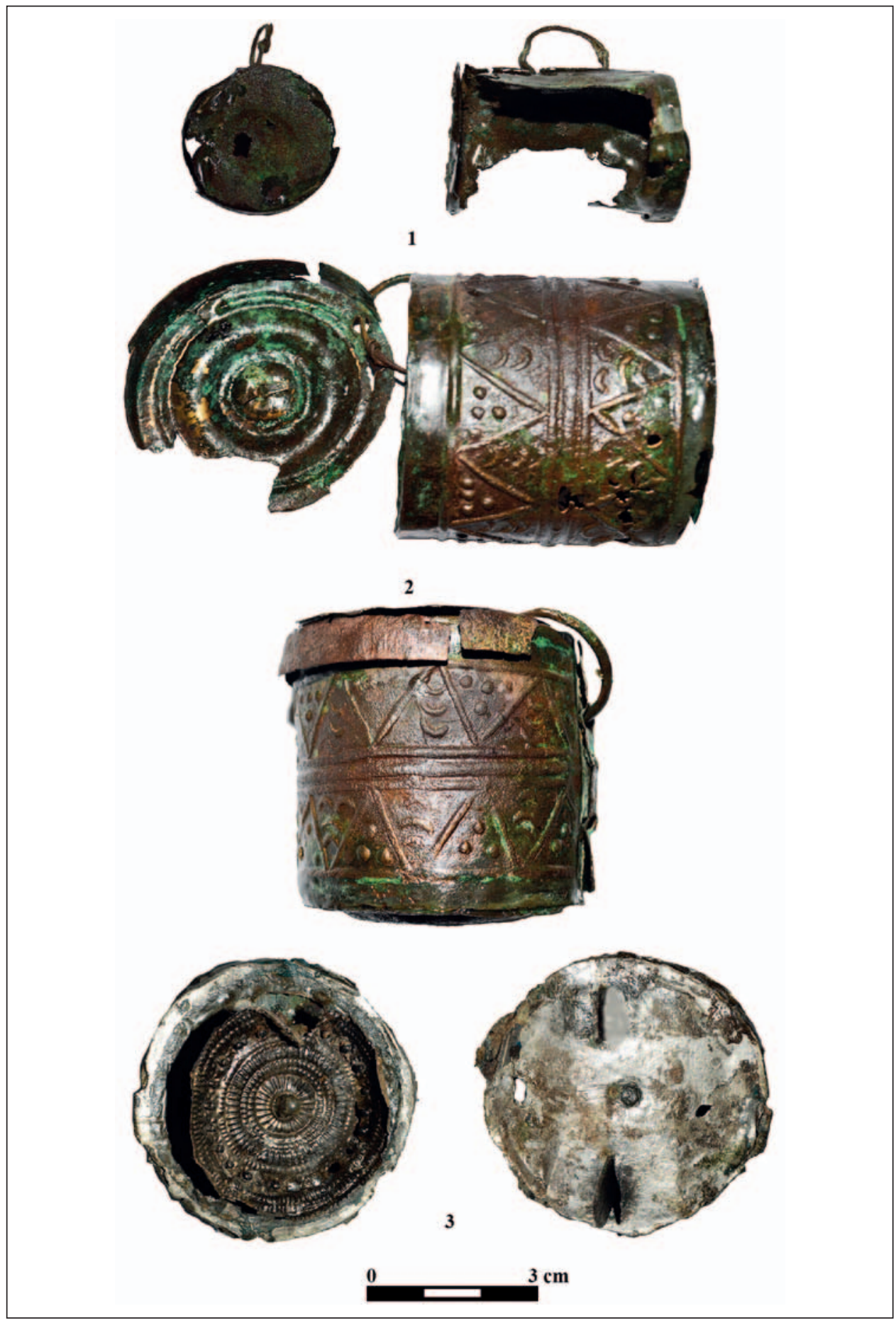

Fig. 4. Objects belonging to the inventory of grave 3 at Hunedoara Timișană. 1-2. Bronze pyxides; 3. Silver brooch. 


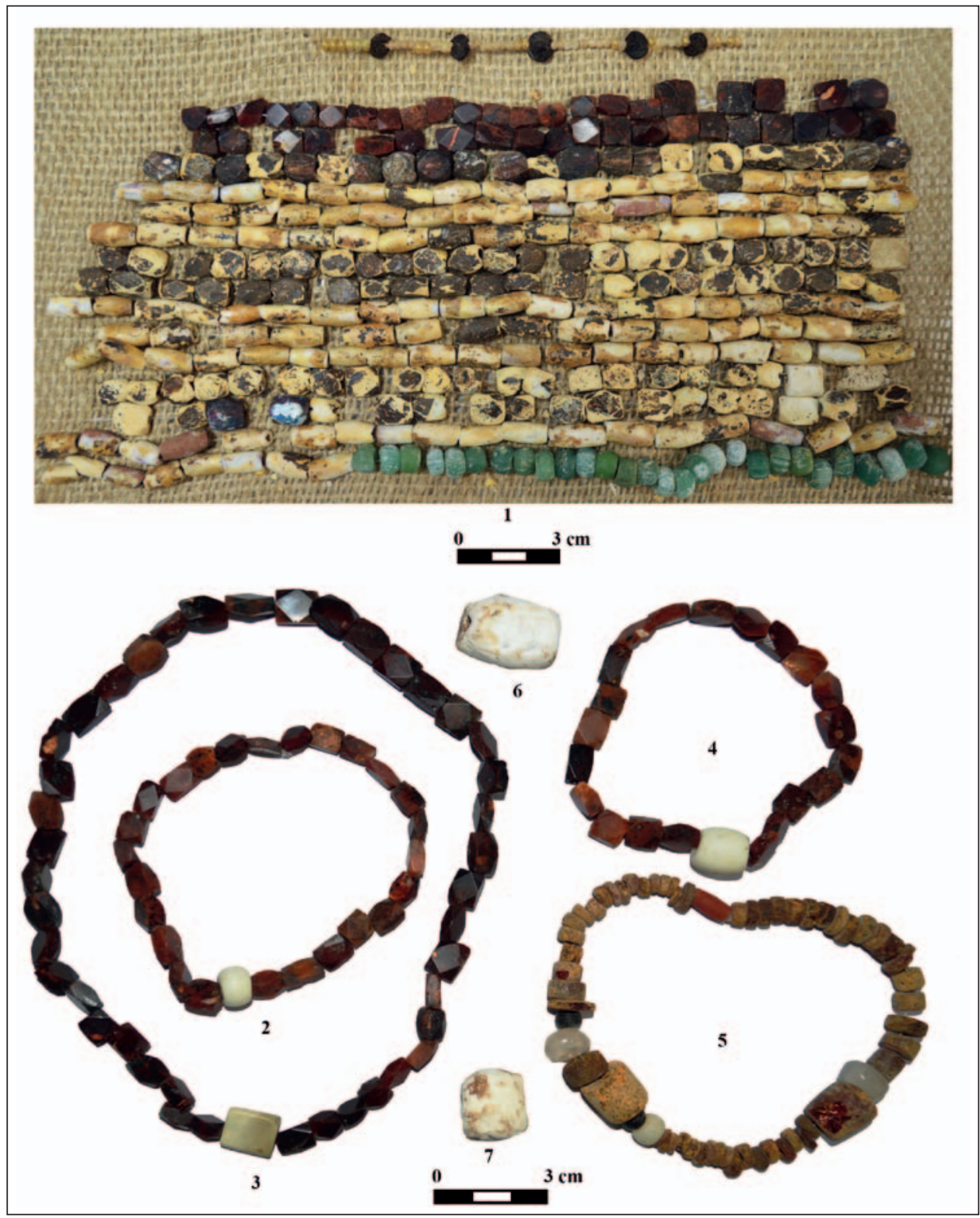

Fig. 5. Beads belonging to the inventory of grave 3 at Hunedoara Timișană.

Grave 7 (G 7), to which belongs the third iron sheet-made pyxis, is characterized by a rectangular, round cornered grave pit oriented NNW-SSE (Fig. 6). The exact position of the skeleton could not be determined owing to the few identified osseous remains. The body preserved anatomically the skull and spine (Fig. 6). This indicates that the deceased lay in supine position with the head towards the NNW. On the floor of the grave pit were scattered small 


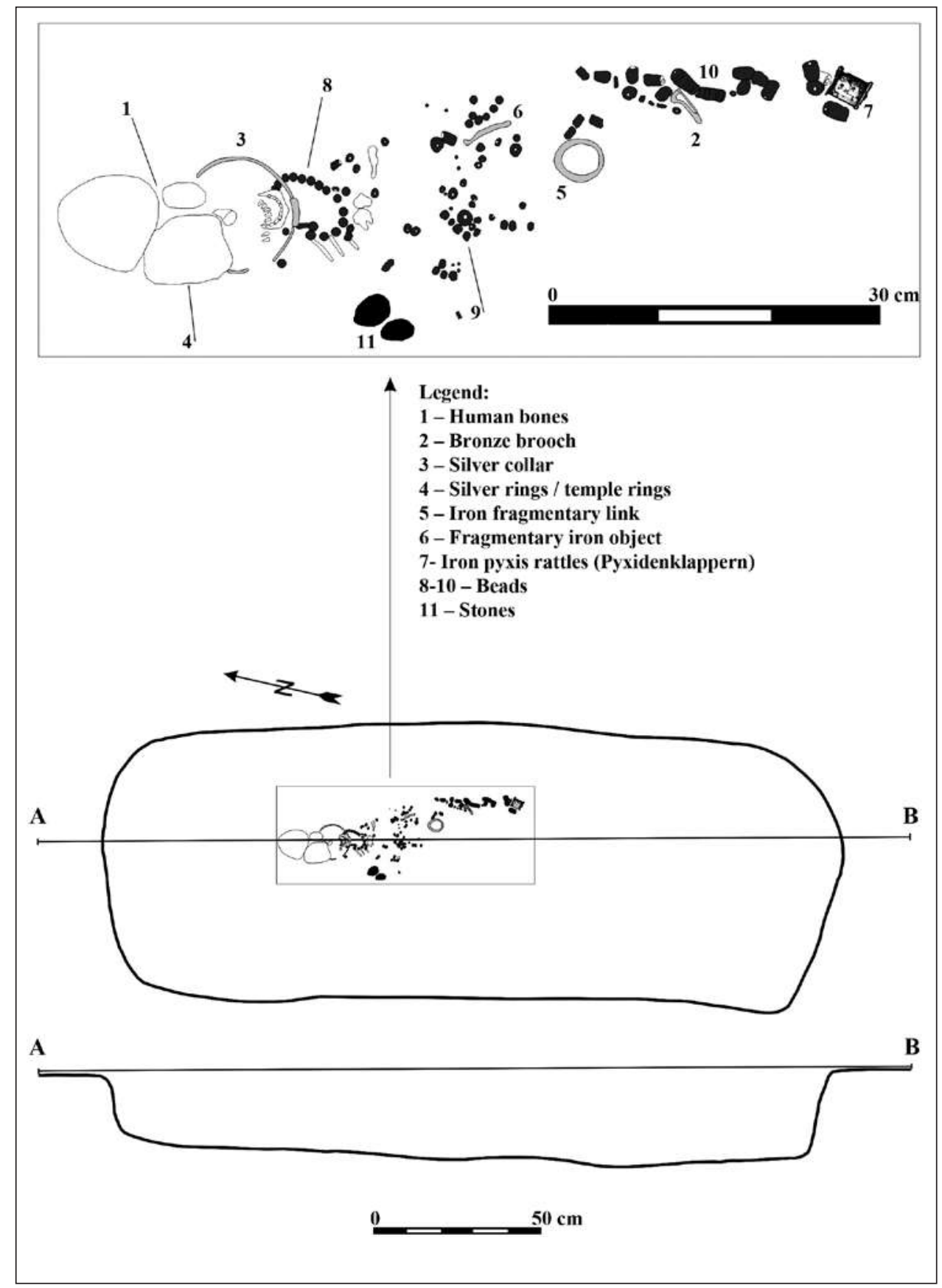

Fig. 6. Grave 7 at Hunedoara Timișană. Legend: 1. Human bones; 2. Bronze brooch; 3. Silver collar; 4. Silver rings / temple rings; 5 . Iron fragmentary link; 6 . Fragmentary iron object; 7. Iron pyxis rattles (Pyxidenklappern); 8-10. Beads; 11 . Stones. 
pieces of a white solid material (limestone/chalk). Analysis of the osseous remains evidenced that the deceased was a child age 4-5 years.

The grave goods included a silver collar, two silver ring-shaped links with overlapping twisted ends, fragments of a strongly corroded iron object, an iron fragmentary link and 169 beads, to which is added a fragmentarily preserved bronze brooch made of a single metal piece with arched bow, rectangular-flat in cross-section, while the partially preserved foot was returned and wound onto the bow (Fig. 6-8; 10). The grave dates to sometime in the chronological interval between the end of the 2 nd and the third-quarter of the 3 rd century AD (cf. V. Bârcă 2014).

G 7 is part of the first group of graves which included graves 4, 7, 8, 9, 10, $11,12,13,14$, plus the grave damaged by the construction of the early medieval house (cf. V. Bârcă 2014), while the second group, to which G 3 belongs, lay ca. 30 m south the first and comprised graves 1, 2, 3, 5, 6, 17 (cf. V. Bârcă 2014). These distinct groups, not delimited by ditches or other constructions, may have had the funerary space divided according to ethnic (origin into a certain distinct group) or social criteria (cf. V. Bârcă 2014). Nor may one exclude the possibility that there was a chronological gap between the two groups, even though all date to the period between the end of the Marcomannic Wars and the third quarter of the 3rd century AD (stages C1a - C1b/C2 in the Central European chronology) (cf. V. Bârcă 2014).

The first pyxis in G 3 is a bronze cylinder-shaped specimen provided with a lid. It was found between the tibia bones below the knee, beside a second pyxis. It is made of three parts. The body proper is made of a strip of bronze sheeting whose ends are attached by soldering. The body surface is decorated with geometric motifs in relief made by dotting. The base is round and attached to the body by soldering, while the lid, also made of bronze sheet, is detachable. The latter was attached to the pyxis body by a bronze wire link with overlapping, twisted ends. Another link, which has not survived, was attached midway to the pyxis body as evidenced by the two attachment orifices. The body piece is $5.6 \mathrm{~cm}$ long, the base diameter being $5 \mathrm{~cm}$ and the lid diameter, $5.3 \mathrm{~cm}$; the bronze sheet is $1 \mathrm{~mm}$ thick (Fig. $3 / 3 ; 4 / 2 ; 9 / 2-3$ ). The pyxis contained a sulphur nugget. The link placed midway down the body would suggest that it was worn, most likely hung from the belt/braid of the dead. This would be further confirmed by the position in which it was found.

A specimen identical with the above comes from the richly furnished Sarmatian grave 121 at Kiskundorozsma-Subasa (Bozsik 2003, 102, Fig. 7/6, 
$8 / 6)^{1}$. Its grave goods included two bracelets, a collar, a bell, a shell pendant (cypraea, cf. Kovács, Vaday 1999, 259)2 a cross-bow brooch (Armbrustfibel) and a large number of beads, noteworthy among which are those identified in several successive rows by the ankles (K. Bozsik 2003, Fig. 4-13), similar to those found in G 3 at Hunedoara Timişană. The Kiskundorozsma-Subasa grave goods indicate, in our view, a date sometime in the second half of the 3 rd century AD (end of stage $\mathrm{C} 1 \mathrm{~b}-\mathrm{C} 2$ in the Central European chronology).

The second bronze sheet pyxis in $\mathrm{G} 3$ lay beside the first. It was smaller and consisted of three parts: the body proper, made of a thin bronze sheet strip; the circular base attached very securely to the body and decorated by dotting; and finally the detachable lid with a central projection. The pyxis had attached to its cylinder body an attachment link made of bronze wire with twisted ends. It was $4.2 \mathrm{~cm}$ long, having a diameter of $2.71 \mathrm{~cm}$; and was made of a sheet less than $1 \mathrm{~mm}$ in thickness (Fig. $3 / 4 ; 4 / 1 ; 9 / 2-3$ ). Traces of white pigments were discovered inside the pyxis.

The iron sheet piece found in G 7 is smaller (height $-2.7 \mathrm{~cm}$, diameter $3.3 \mathrm{~cm}$ ) than the second specimen in G 3. It was made of three parts: the body made of iron sheet and two circular ends or lids (one of which did not survive) made of the same metal, whose edges were crimped and seem to have been soldered (at least in the case of the surviving side) over the edges of the cylinder body. The body and surviving side exhibit an orifice where the attachment link was inserted. Inside were preserved small remains of a solid substance/material, which, however, could not be identified (Fig. 7/7).

Complete or fragmentary specimens, similar or very close to the latter, have been identified in several Sarmatian graves of the Great Hungarian Plain: Nagykörü-Marsó (Párducz 1941, Pl. XXII/4; Vaday 1989, 124, 259, cat. no. 214/8, Pl. 74/11); Kisújszállás-Porosállás (Párducz 1950, 26, Pl. LXXIV/3, 5; Vaday 1989, 124, 247-248, cat. no. 147/7, Pl. 47/2, 5); G 1933/1 at Törökszentmiklós-Surján, Barta Pusta (Párducz 1950, III, Pl. LXXII/9; Vaday 1980, 57, Pl. 19/2; Vaday 1989, 124, 281, cat. no. 396/3, Pl. 153/8); Törökszentmiklós-Surján, Újtelep (Vaday 1985, 361, Fig. 15/8-9; Vaday 1989, 124, 284, cat. nr. 411/5-6, Pl. 127/5-6); G 53 at Tápiószele (Párducz 1950, 69, 70-71, Pl. XIV/2/1a-e; Vaday

Kiskundorozsma is near Szeged (Hungary).

2 Shell pendants (cypraea) are missing from the Sarmatian graves in the Great Hungarian Plain during the period prior to the Marcomannic Wars, being recorded mainly starting with the last decades of the 2nd century AD. Cypraea pendants are found in the Sarmatian graves of the Great Hungarian Plain until the second half of the 3rd century AD, when they disappear. They re-emerge once again in the last third of the 4th century $\mathrm{AD}$, possibly brought back again by new Iranian and Germanic groups. It is believed that shell pendants (cypraea) were brought to the Great Hungarian Plain and are both chronological markers and markers indicating the arrival of immigrants to the area. 


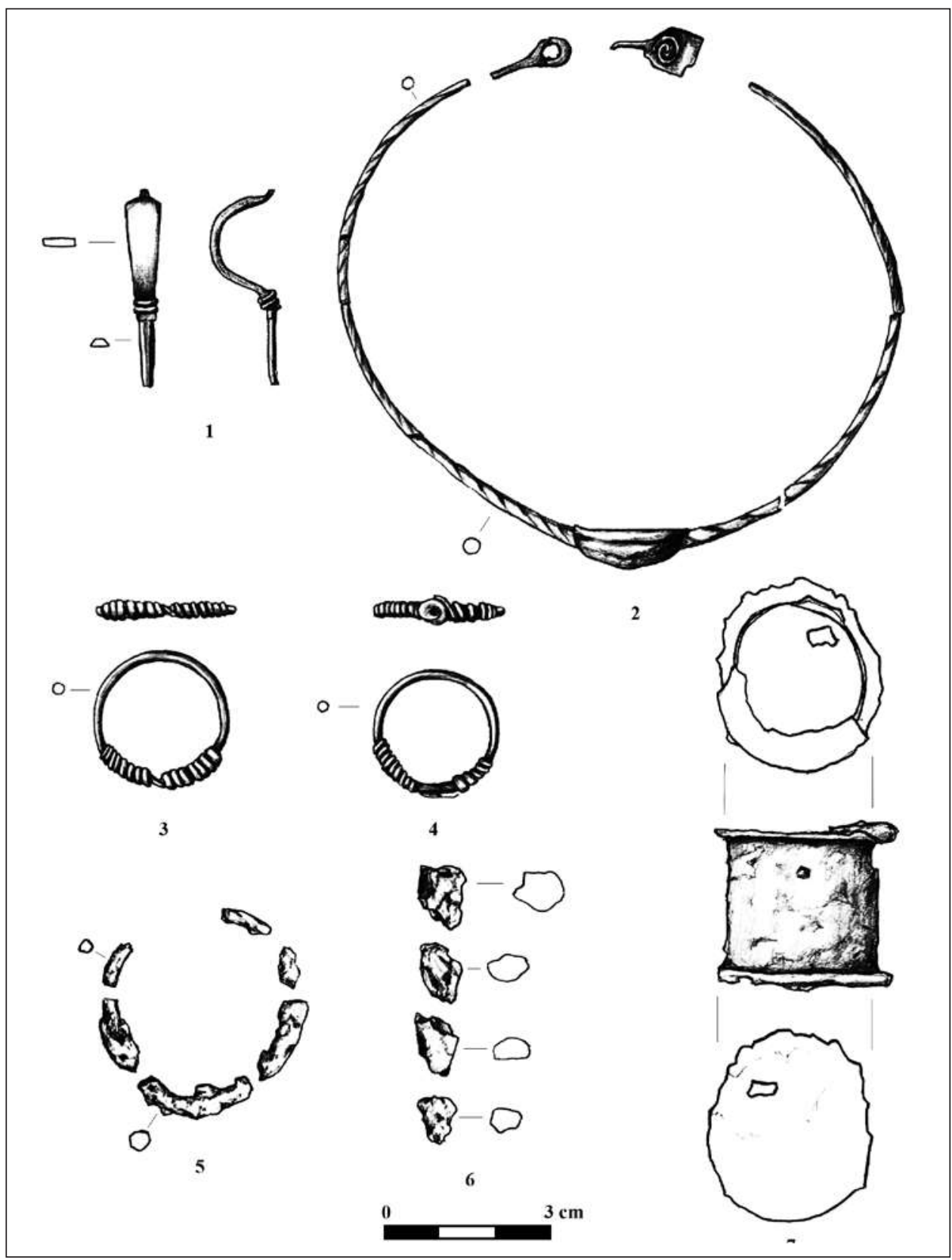

Fig. 7. Objects belonging to the inventory of grave 7 at Hunedoara Timișană. 1. Bronze brooch; 2. Silver collar; 3-4. Silver rings/temple rings; 5 . Iron fragmentary link; 6 . Fragmentary iron object; 7. Iron pyxis rattles (Pyxidenklappern).

1989, 124); G 27 at Endrőd-Szujókereszr (Vaday, Szőke 1983, 82, 113, Fig. 5/23); Hatvan-Budapest (Vaday, B. M. Szőke 1983, 113); G 22 at Szentes-Sárga- 


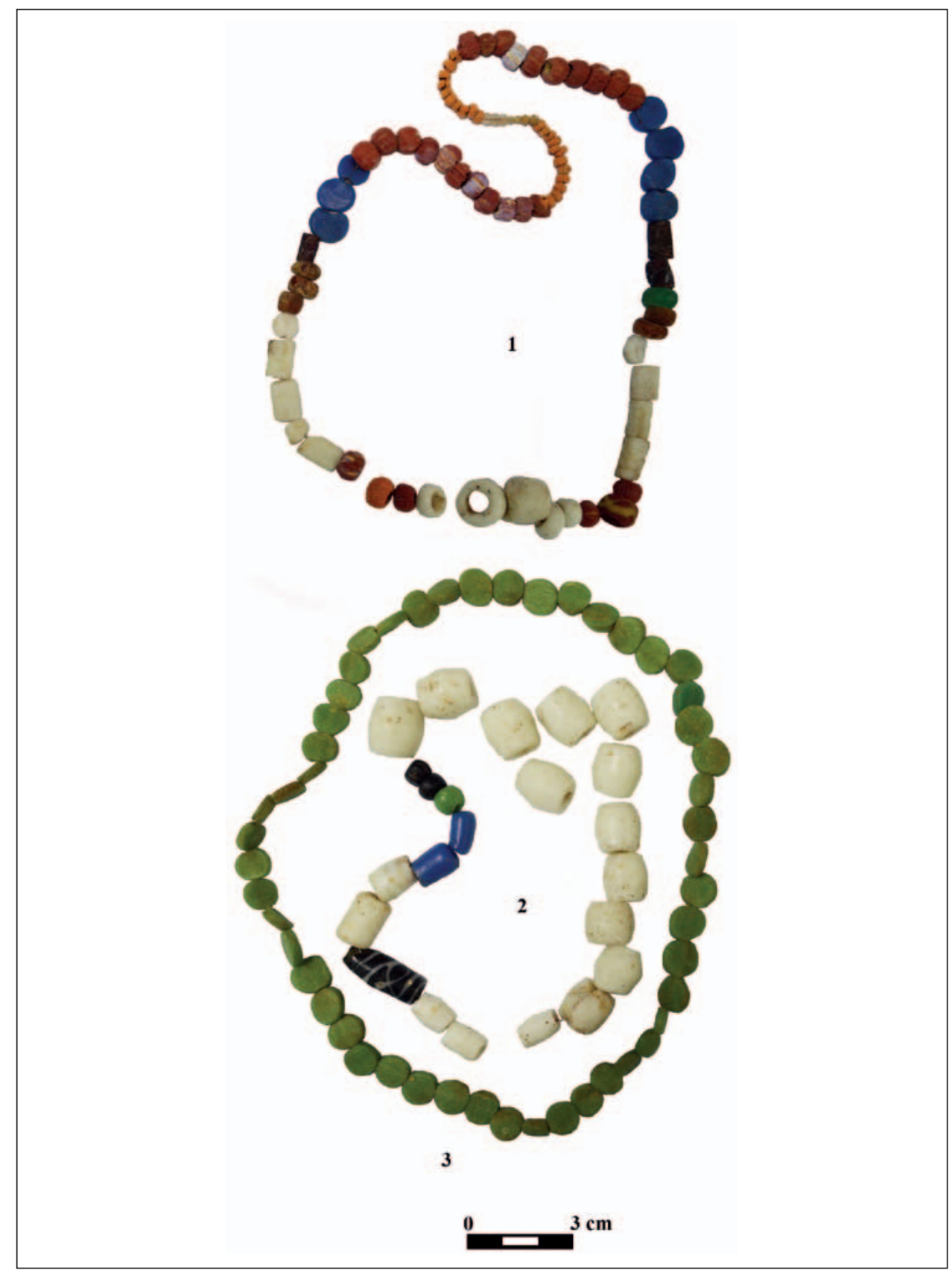

Fig. 8. Beads belonging to the inventory of grave 7 at Hunedoara Timișană.

part (Párducz 1950 III, 9, Pl. VII/5a-b, VIII/7; Vaday, B. M. Szőke 1983, 113) or G 24 at Szeged-Csongrádi út (Vörös 1981, 127, Fig. 10/8-9)), including the territory between the Lower Mureş, Tisza and Danube (graves 6, 9, 10, 11 in 
the cemetery at Vršac-Dvorište Eparhije Banatska (Barački 1961, Pl. IV/10, VII/5-6, VIII/3, IX/17; Đordević 1994, Pl. VII/9-10), Vršac-Trg Sava Kovačević (S. Barački 1961, 142, Pl. XV/10-11), or grave 24 at Pančevo-Vojlovica, whence come three specimens (Batistić-Popadić 1985, 62-63, Pl. V/79). Interestingly, as in the case at Hunedoara Timişană (G 3), some were provided on one end with a detachable lid. Some specimens, however, such as the piece in $G 7$, had both ends (lids) securely attached to the body, being crimped and attached over the body of the pieces, as, for instance, the specimens in the graves at Vršac-Dvorište Eparhie Banata, and those from Törökszentmiklós-Surján, Újtelep. The detachable lids of the pyxides in G 1933/1 at Törökszentmiklós-Surján, Barta Pusta and Nagykörü-Marsó are almost identical with that of the second specimen in G 3 at Hunedoara Timişană (Fig. 3/4; 4/1; 9/2-3).

Most of these artifacts are decorated by dotting, and some preserve also the attachment link of bronze wire with overlapping, twisted ends, which suggest that they were most likely suspended on the belt/braid.

Two main applications have been suggested for the specimens in the Sarmatian environment of the Great Hungarian Plain: paint recipients (Farbenbehälter) and rattle pyxides (Pyxidenklappern, Vaday 1989, 123-124).

For the finds in graves 6, 9, 10, 11 in the cemetery at Vršac-Dvorište Eparhie Banata and Törökszentmiklós-Surján, Újtelep it was believed, based on the fact that their ends (lids) were crimped and soldered to the cylinder body, that they were not pyxides as they could not be opened (Barački 1961, 138; Vaday, 1985, 372; Vaday 1989, 124). Inside one of the specimens at Vršac-Dvorište Eparhie Banata a potshard was found, which may evidence its use as a rattle (Pyxidenklapper), being hung from the belt/braid end of the dead (Barački 1961, 138; Vaday 1980, 372; Vaday 1989, 124). This aspect, identified mainly in the case of the specimens at Vršac-Dvorište Eparhie Banata, led the Serbian scholar D. Batistić-Popadić to attribute to the specimens at Pančevo-Vojlovica an additional magical-apotropaic role (Batistić-Popadić 1985, 68). Given all the above, it is very likely that the specimen in $\mathrm{G} 7$ at Hunedoara Timişană also was used as rattle (Pyxidenklapper), making it instead a pendant.

Even though the precise function of the pieces in the Sarmatian grave is difficult to establish, especially in those only fragmentarily preserved, it is obvious that, in the case of the specimens from G 3 at Hunedoara Timişană, as in those provided with detachable ends, they were used as containers for preserving cosmetic paints, powder substances, aromatic herbs, mineral materials or medicinal herbs believed to be healing. In fact, the presence in the large pyxis 
(Fig. 7/5) of a sulphur nugget and of white pigments in the smaller (Fig. 7/3) confirm the above.

Pyxides similar to those at Hunedoara Timişană (G 3) have also noted at other sites in the Sarmatian environment of the Great Hungarian Plain. For instance, traces of white and red pigments were detected in pyxides from G 53 at Tápiószele, leading M. Párducz to conclude that they were substances used for facial make-up or tattooing (Párducz 1950, 71). A white powdery substance (pigment) was also found in the pyxis from G 27 at Endröd-Szujókereszt (Vaday, Szőke 1983, 113; Vaday 1989, 124). Parenthetically, we mention also pyxides/ capsules from the Sarmatian grave $(\mathrm{X} / 2 / \mathrm{A})$ of the Late period from Szihalom-Budaszög that contained herbal residue (Coriandrum sativum) together with a series of substances, which very likely were used as make-up (Fodor 1997, 120, 121, Fig. 120-121, 191, cat. no.XVI/27, XVI/28; Vida 2009, 269. For the analysis of the substances in these pieces see Sándor 2009, 281-286). The specimens at Szihalom-Budaszög were provided with detachable lids; one had the lid attached to the body by a wire link with ends overlapped and twisted (Fodor 1997, Fig. 121, cat. no. XVI/28; Vida 2009, Fig. 6). A piece very similar to the specimens in the Sarmatian graves of the Great Hungarian Plain comes from G 123 in the cemetery at Zemplin, Slovakia (Budinský-Krička 1990, 297, $\mathrm{Pl}$. XVI/40). It has the body and lid decorated by dotting. The lid is detachable and provided with an attachment link. Two similar specimens come also from the Carpian environment - Pădureni, Romania (Bichir 1973, 111-112, Pl. CLXII/2-3; CLXIII/4, 11; Ioniță 1982, 66, Fig. 16/3, 7)33. One of them has the body decorated with geometric motifs in relief made by dotting and a detachable lid provided with attachment mechanism. The second piece has also a detachable lid provided with attachment mechanism to which is attached a link overlapped and twisted. Midway down the cylinder body it is provided with the same attachment mechanism as the lid, which indicates it was worn suspended.

Therefore, it may be argued with certainty that, like the pyxides from the rest of the eastern Sarmatian world, the specimens with such functionality from the Great Hungarian Plain, the Sarmatian environment included, were used to preserve both cosmetic products as well as various healing medicinal herbs (cf. Vida 2009, 270).

In terms of these artifacts' dating in the Sarmatian environment of the Great Hungarian Plain it must be mentioned they come from graves of different chron-

3 I. Ioniță believed they are pendant-boxes functioning as amulets (Ioniță 1982, 66-67). 


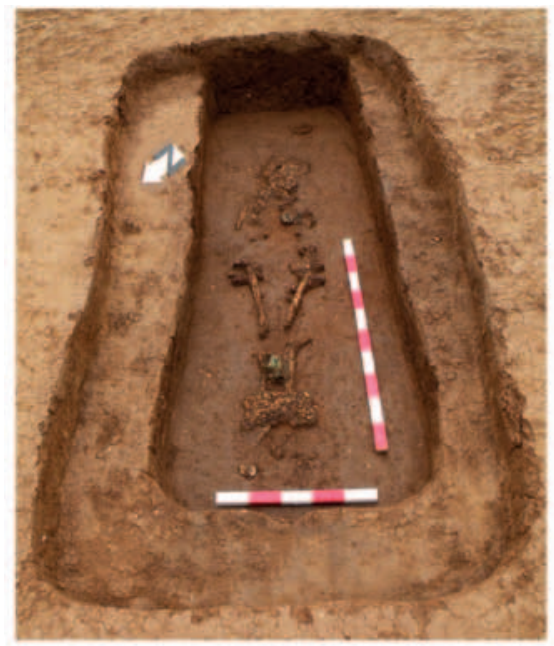

1

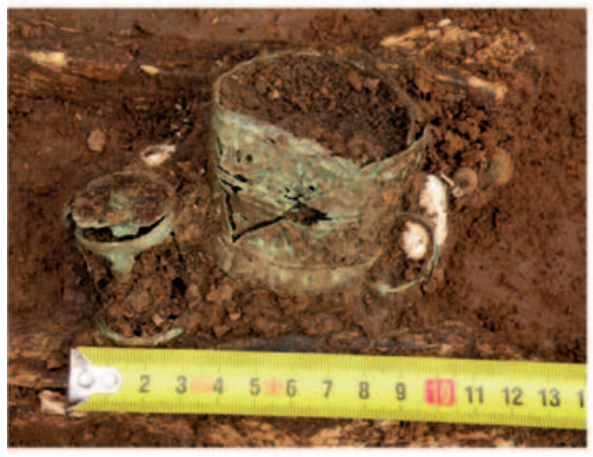

3

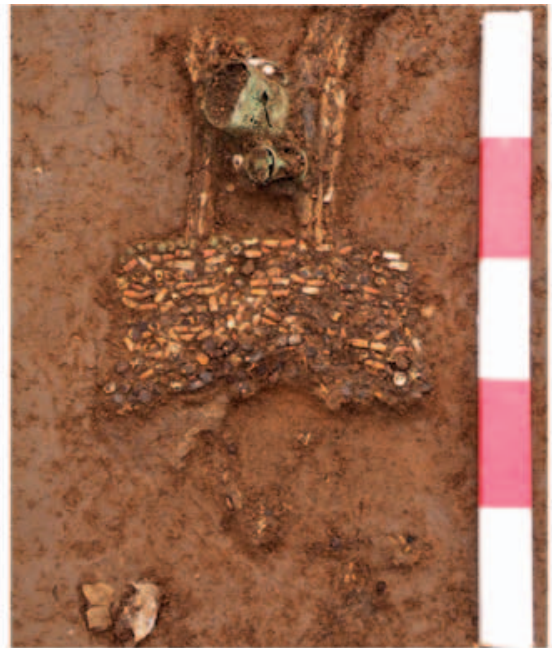

2

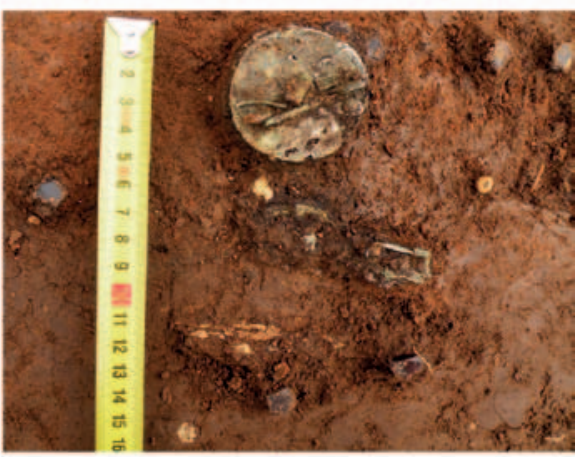

4

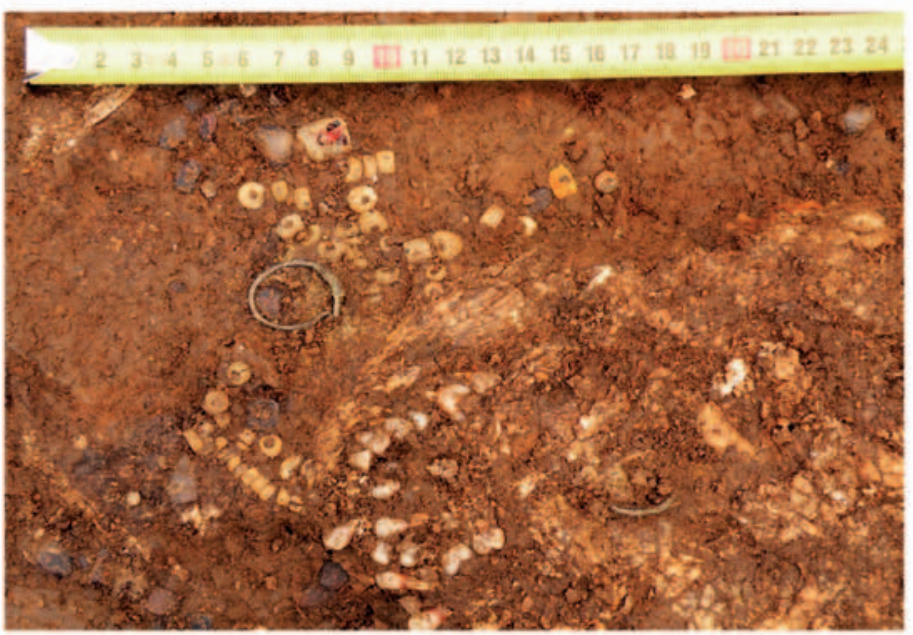

5

Fig. 9. Grave 3 at Hunedoara Timișană. 
ological intervals. For instance, the piece at Nagykörü-Marsó was discovered beside a series of artifacts (see for the grave goods of this grave Párducz 1950, I, 55, Pl. XXII, XXX/9-13; Vaday 1989, 259, cat. no. 214, Pl. 74), including a gold lunula pendant, which dates the grave sometime by early/first decades of the 2nd century AD, part of the group of remains of the so-called "golden horizon". Grave 1933/1 at Törökszentmiklós-Surján, Barta Pusta, whose grave goods also contained a silver returned-foot outer-chord brooch made of a single metal piece (type Almgren 158. Cf. For the furnishing of this grave Párducz 1950, III, 2425, Pl. LXXII/8-10, XXIX/16-17; Vaday 1980, 57-58, Pl. 19/1-7, 20/1-4; Vaday 1989, 281, cat. nr. 396, Pl. 153/7-10), dates, in our view, to sometime to the 3rd century AD (stages C1b - C2 in the Central European chronology).

Also dating to sometime in the 3rd century AD is the grave at Törökszentmiklós-Surján, Újtelep, whose grave goods also contained a bronze returned foot brooch (Vaday 1980, 361, Fig. 15/3; Vaday 1989, 284, cat. no. 411/7, Pl. 127/7). Dating much earlier is G 53 at Tápiószele, whose grave goods included, beside the bronze pyxis, several bead types, a bell, knotted links, but also a gold lunula pendant (Párducz 1950, 69, 70-71, Pl. XIII-XIV). The grave is part of that group of finds ascribed to the so-called "golden horizon" dated mainly to the chronological interval between the last quarter/end of the 1st century and early/first decades of the 2nd century $\mathrm{AD}$ (for the analysis of these finds and views see Istvánovits, Kulcsár 2006, 203-237; Bârcă 2014; Bârcă 2016, 7-66). To this group also belongs G 24 at Szeged-Csongrádi út whose funerary furnishings contain, beside pyxides, a gold lunula pendant and gold leaf tubular pieces (see for the furnishing of this grave Vörös 1981, 126-128, Fig. 5-6, 10/7-9, 11/1-2; Kőhegyi 1984, 318-321).

Sometime to the second half of the 2 nd century dates G 27 at Endrőd-Szujókereszr, whose furnishing included, beside the pyxis, other classes of artifacts and a disc enamelled brooch (for the analysis of this brooch type and that of the specimen at Endröd-Szujókereszr see Vaday 2003, 344, 391, cat. nr. $34 / 1$, tipul III/5/2/2, Fig. 15), whose edge was decorated with six nearly circular projections, set symmetrically (Vaday, Szőke 1983, 82, Fig. 3/10).

The surviving detachable lid of the pyxis in G 22 at Szentes-Sárgapart (Párducz 1950, 9, 133, III, Pl. VIII/7) is quite similar to that of the first pyxis in G 3 at Hunedoara Timişană. The furnishing of the grave at Szentes-Sárgapart contains a brooch with a vertical catch plate, in the variation with a head knob and outer chord (group Almgren VII series I). The belongs to the sub-variation used in the Sarmatian environment of the Great Hungarian Plain mainly during the chronological interval comprised between the last two decades of the 2nd - mid 3rd century AD (stages Cla-Clb. See for the analysis of the brooches in this type Cociş, Bârcă 2014, 189-214). 

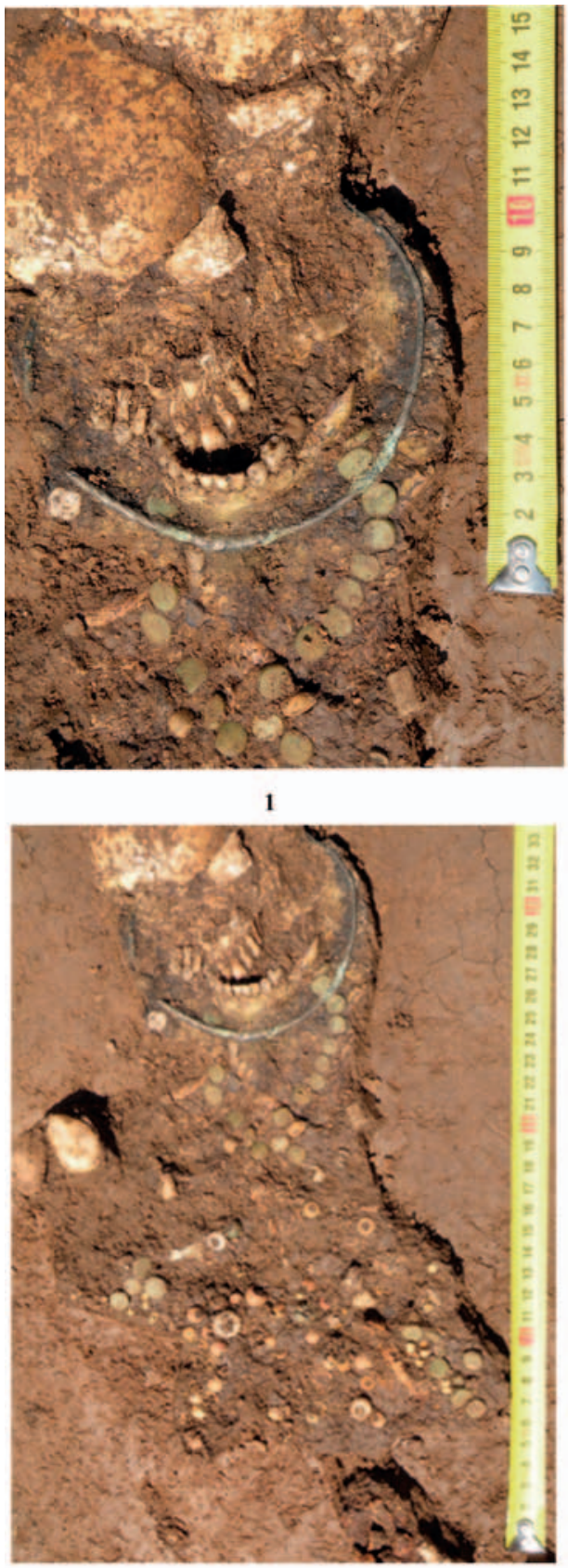

3

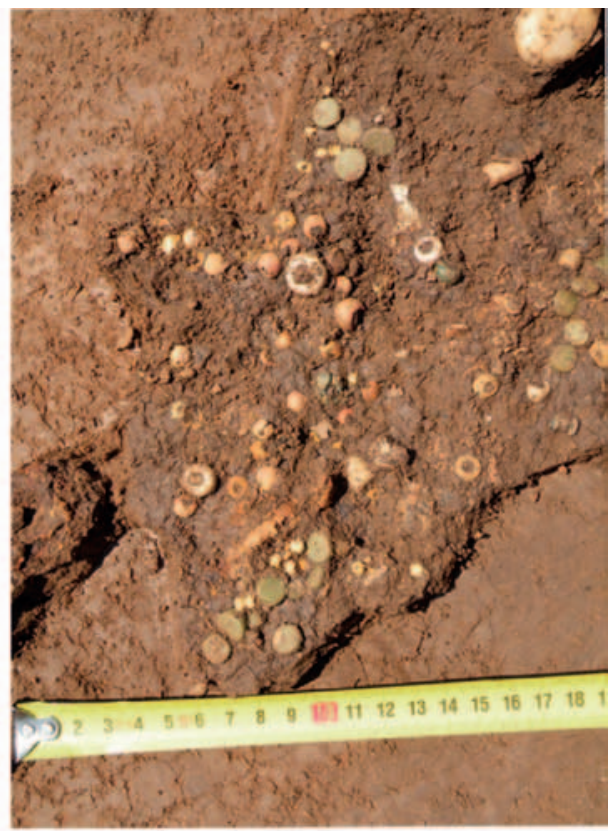

2

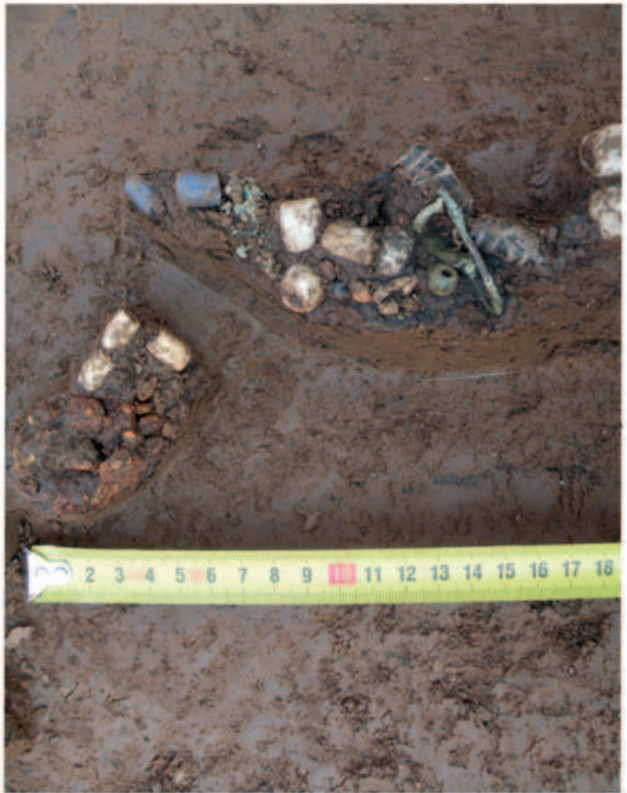

4

Fig. 10. Grave 7 at Hunedoara Timișană.

In terms of the pieces from the territory between the Lower Mureş, Tisza and Danube (graves 6, 9, 10, 11 in the cemetery at Vršac-Dvorište Eparhije 
Banatska (Barački 1994, Pl. VII/9-10), Vršac-Trg Sava Kovačević (Barački 1961, 142, Pl. XV/10-11) or grave 24 at Pančevo-Vojlovica (Batistić-Popadić 1985, 6263 , Pl. V/79), from where come three specimens), one must mention that their grave goods date to sometime over the 3rd century AD. In G 6 at Vršac-Dvorište Eparhije Banatska there was a disc enamelled brooch (Barački 1961, 119, Pl. IV/12), in G 9 a silver box-type brooch (Dosenfibel) decorated in the middle with a glass intaglio with an anthropomorphic depiction (Barački 1961, 120, Pl. VII/16a-b; Petković 2010, 177, cat. no. 948, Type 21/D1, 357, 366), and in $\mathrm{G} 10$ a disc bronze brooch, with a central intaglio depicting a human face (Barački 1961, 120, Pl. VIII/5a-b). In fact, the grave goods in the cemetery at Vršac-Dvorište Eparhije Banatska count Pelta brooches, enamelled brooches, crossbow brooches, specimens with vertical catch plate, the variation with head knob and outer chord (group Almgren VII series I), but also box-type brooches (Dosenfibel). All, evidence, beside other artifact classes, that most graves in the cemetery at Vršac-Dvorište Eparhije Banatska date to the 3rd century AD (for the graves in this cemetery see Barački 1961).

A careful analysis of metal pyxis and rattle pyxis (Pyxidenklappern) finds shows they are not often recorded in the Sarmatian cemeteries of the Great Hungarian Plain. Furthermore, their find area is restricted mainly to the middle and lower Tisza river basin, including in the territory between the Lower Mureş, Tisza and Danube.

Finally, it may be noted that graves in the southern half of the Great Hungarian Plain, whose grave goods contained pyxides provided with detachable lids and rattle pyxides (Pyxidenklappern) belong to the horizon of 3rd century Sarmatian remains in the region.

In terms of the specimens in G 3 at Hunedoara Timişană we believe them to likely be artifacts made by a Roman artisan, possibly travelling, who was active in the area of economic interaction adjacent to the limes, where intensive trade between the Romans and Sarmatians occurred.

Lastly, we conclude that the metal pyxides from the Sarmatian environment of the Great Hungarian Plain, like those in the rest of the eastern Sarmatian world, were used to preserve both cosmetic products as well as various healing medicinal herbs.

\section{Acknowledgments}

This work was supported by grants of the Ministry of National Education, CNCS - UEFISCDI, project number PN-III-P4-ID-PCE-2016-0737. 


\section{Bibliography}

Arkheologiya SSSR. Stepi evropejskoj chasti SSSR v skifo-sarmatskoe vremya 1989. Moskva: Nauka, 1989.

Arkheologiya Ukrainskoj SSR. 1986. II. Kiev: Naukova dumka.

Barački, S. 1961. "Sarmatskie nalazi iz Vršca”. Rad muzeja Vojvodine 10: 117-143

Bârcă V. et alii. 2011. "Hunedoara Timişană, com. Şagu, jud. Arad, Punct: Autostrada Arad-Timişoara, tronson Arad-Seceani, km 23+170 - 23+690 (siturile B0_7-B0_8)", Cronica cercetărilor arheologice din România, Campania 2010. Sibiu: 187-192.

Bârcă, V. 2006. Istorie şi civilizație. Sarmații în spațiul est-carpatic (sec. I a. Chr. - inceputul sec. II p. Chr.). Cluj-Napoca: Argonaut.

Bârcă, V. 2014. Sarmatian vestiges discovered south of the Lower Mureş River. The graves from Hunedoara Timişană and Arad. Cluj-Napoca: Mega.

Bârcă, V. 2016. "The dating of the Sarmatian grave at Sânnicolau Mare Selişte (Timis county, Romania) and the issue of the early Sarmatian entry and settlement of the Pannonian Plain." Ephemeris Napocensis XXV: 7-66.

Bârcă, V., and L. Grumeza. 2014. "Sarmatian Burials in Coffins and Funerary Timber Features Recently Discovered in the Western Plain of Romania”. Ephemeris Napocensis XXIV: 157-194.

Bârcă, V., and O. Symonenko. 2009. Călăreții stepelor. Sarmații în spațiul nord-pontic. Cluj-Napoca: Mega.

Batistić-Popadić, D. 1985 “Sarmatska nekropola Vojlovica-Pančevo". Rad muzeja Vojvodine 29: 59-83.

Béal, J.-C., and M. Feugère. 1983. Les pyxides gallo-romaines en os de Gaule méridionale. Documents d’Archéologie Méridionale 6: 115-126.

Bespalyj, E. I. 1992. "Kurgan sarmatskogo vremeni u g. Azova”. Sovetskaya Arkheologiya 1, 175-191.

Bichir, Gh. 1973. Cultura carpică. Bucharest: The Publishing House of the Socialist Republic of Romania Academy.

Bíró, M. T. 1994. The Bone Objects of the Roman Collection. In memoriam Gizella Erdélyi. Catalogi Musei Nationalis Hungarici, Series Archaeologica II. Budapest: Magyar Nemzeti Múzeum.

Bozsik, K. 2003. "Szarmata sírok a Kiskundorozsma-subasai 26/78. Lelőhelyen.” In Úton-útfélen. Múzeumi kutatások az M5 autópálya nyomvonalán, edited by Cs. Szalontai, 97-106. Szeged: Móra Ferenc múzeum.

Budinský-Krička, V., and M. Lamiová-Schmiedlová. 1990. "A late 1st century BC - 2nd century AD cemetery at Zemplin”. Slovenská Archeologia XXXVIII/2: 245-334. 
Cociş, S., and V. Bârcă. 2014. “The 'Sarmatian' brooches (headknob and full catchplate variant, Almgren group VII, series I) in the Dacia province and the barbarian environment of the Tisza river basin." Dacia N. S. LVIII: 189-214.

Đordević, M. 1994. "Nalazi nekropola rimskog perioda u Jugozapadnom Banatu”. Rad muzeja Vojvodine 36: 41-61.

Fodor, L. 1997. “Szihalom-Budaszög. Késő szarmata-kora népvándorlás kori temető a IV-V. századból (Late Sarmatian and Early Migration Period cemetery from the a.d. 4th-5th century).” In Utak a múltba. Az M3-as autópálya régészeti leletmentései (Paths into the past. Rescue excavations on the M3 Motorway). edited by P. Raczky, T. Kovács, A. Anders, 120-123. Budapest: Magyar Nemzeti Múzeum.

Gushchina, I., and I.P. Zasetskaya. 1994. "Zolotoe kladbishche" rimskoj epokhi v Prikuban'e. Sankt-Peterburg: Farn.

Ioniță, I. 1982. Din istoria şi civilizaţia dacilor liberi. Dacii din spațiul est-carpatic in secolele II-IV e. $n$. Iaşi: Junimea.

Istvánovits, E., and V. Kulcsár. 2006. "Az első szarmaták az Alföldön (Gondolatok a Kárpát-medencei jazig foglalásról)”. Jósa András Múzeum Évkönyve XLVIII: 203-237.

Kőhegyi, M. 1984. ”Kora szarmata aranyleletes női sírok az Alföldön”. Déri Múzeum Évkönyve 1982: 318-321.

Kostenko, V.I. 1983. Sarmatskie pamyatniki Dnepro-Donskogo mezhdurech'ya III v. do n. e. - III v. n.e. Dnepropetrovsk: Izdatel'stvo DGU.

Kostenko, V.I. 1993. Sarmaty v Nizhnem Podneprov'e (po materialam Ust'-Kamenskogo mogil'nika). Dnepropetrovsk: Izdatel'stvo DGU.

Kovács, L., and A. Vaday. 1999. "On the problem of the marine gastropod shell pendants in the Sarmatian Barbaricum in the Carpathian Basin" in Pannonia and Beyond - Studies in Honour of László Barkóczi (Antaeus 24). edited by A. Vaday, 247-277.

Kovpanenko, G. T. 1986. Sarmatskoe pogrebenie I v. n. e. na yuzhnom Buge. Kiev: Naukova dumka.

Marčenko, I.I., and N.Ju. Limberis. 2008. "Römische Importe in sarmatischen und maiotischen Denkmälern des Kubangebietes”, In A. Simonenko, I.I. Marčenko, N.Ju. Limberis, Römische Importe in sarmatischen und maiotischen Gräbern zwischen Unterer Donau und Kuban. Archäologie in Eurasien 25, 265400. Mainz: Philipp von Zabern.

Melyukova, A.I. 1962. "Sarmatskoe pogrebenie iz kurgana u s. Oloneshty (Moldavskaya SSR)”. Sovetskaya Arheologiya 1:195-208.

Mordvintseva, V., and M. Trejster. 2007. Proizvedeniya torevtiki i yuvelirnogo iskusstva $v$ Severnom Prichernomor'e 2 v. do n. e. -2 v. n. e. I-III. Simferopol'-Bonn: Tarpan. 
Párducz, M. 1941. A szarmatakor emlékei Magyarországon I / Denkmäler der Sarmatenzeit Ungarns I (Archaeologia Hungarica XXV). Budapest: Országos Magyar Történeti Múzeum.

Párducz, M. 1950a. "Szarmata sírok Tápiószelén”, Archeológiai Értesitö 77: 67-51

Párducz, M. 1950b. A szarmatakor emlékei Magyarországon III / Denkmäler der Sarmatenzeit Ungarns III (Archaeologia Hungarica XXX). Budapest: Országos Magyar Történeti Múzeum.

Petković, S. 2010. Rimske fibule u Srbiji od I do V veka n. e. Beograd: Arkheološki institut.

Petru, S. 1972. Emonske nekropole. Odkrite med leti 1935-1960. Ljubliana: Narodni muzej.

Puzdrovskii, A. E. 2007. Krymskaya Skifiya II v. do n. e. - III v. n. e. Pogrebal'nye pamyatniki. Simferopol': Biznes-Inform.

Sándor, J. 2009. "Multi-step analysis of ancient remnants contained in a capsule from Szihalom-Budaszög." In Glaube, Kult und Herrschaft. Phänomene des Religiösen im 1. Jahrtausend n. Chr. in Mittel- und Nordeuropa. Akten des 59. Internationalen Sachsensymposions und der Grundprobleme der frühgeschichtlichen Entwicklung im Mitteldonauraum. edited by U. Von Freeden, H. Friesinger, E. Wamers, 281-286. Bonn: Habelt.

Simonenko, A. V. 1981. "Sarmaty v Srednem Podneprov'e". In Drevnosti Srednego Podneprov'ya, 52-69. Kiev: Naukova dumka.

Simonenko, A. V. 2008. "Römische Importe in sarmatischen Denkmälern des nördlichen Schwarzmeergebietes”, In A. Simonenko, I. I. Marčenko, N. Ju. Limberis, Römische Importe in sarmatischen und maiotischen Gräbern zwischen Unterer Donau und Kuban. Archäologie in Eurasien 2, 1-94. Mainz: Philipp von Zabern.

Simonenko, A. V. 2011. Rimskij import u sarmatov Severnogo Prichernomor'ya. Sankt-Peterburg: Nestor-Istoriya.

Sokol'skii, N. I. 1971, Derevoobrabatyvayushchee remeslo $v$ antichnykh gorodakh Severnogo Prichernomorya (Materialy $i$ issledovanya po arkheologii 178). Moskva: Izdatel'stvo Akadenii Nauk SSSR, 1971.

Trejster, M. Yu. 1994. "Sarmatskaya shkola khudozhestvenoj toreutiki (K otkrytiyu serviza iz Kosiki)”. Vestnik drevnei istorii 1: 172-203.

Vaday, A. 1980. "Sarmatisches Gräberfeld in Törökszentmiklós, Surján”. Mitteilungen des Archaologischen Instituts der Ungarischen Akademie der Wissenscheften 8-9: 57-69; 309-324.

Vaday, A. 1985. "Sarmatisches Gräberfeld in Törökszentmiklós-Surján-újtelep”. Acta Archaeologica Academiae Scientiarum Hungaricae XXXVII, 3-4: 345-390. 
Vaday, A. 1989. Die sarmatischen Denkmäler des Komitats Szolnok (Antaeus 17-18). Budapest Archäologisches Inst. der UAW.

Vaday, A. 2003. Cloisonné Brooches in the Sarmatian Barbaricum in The Carpathian Basin, Acta Archaeologica Academiae Scientiarum Hungaricae LIV, 3-4: 315-421.

Vaday, A., and B.M. Szőke. 1983. "Szarmata temetö és gepida sír EndrődSzujókereszten”. Communicationes Archaeologicae Hungaricae 1983:79-132.

Vida, T. 2009. "Herkunft und Funktion von Privatreliquiaren und Amulettkapseln im frühgeschichtlichen Europa" in Glaube, Kult und Herrschaft. Phänomene des Religiösen im 1. Jahrtausend n. Chr. in Mittel- und Nordeuropa. Akten des 59. Internationalen Sachsensymposions und der Grundprobleme der frühgeschichtlichen Entwicklung im Mitteldonauraum. edited by U. Von Freeden, H. Friesinger, E. Wamers, 261-280. Bonn: Habelt.

Vörös, G. 1981. "Adatok a szarmatakori női viselethez". Communicationes Archaeologicae Hungaricae 1981: 121-135.

Vyaz'mitina, M. I. 1954. "Sarmatskie pogrebeniya u s. Novo-Filipovka” in Voprosy skifo-sarmatskoj arkheologii: 220-244.

\section{Observații pe marginea pixidelor metalice recent descoperite în mediul sarmatic de la sud de Mureșul Inferior}

\section{Rezumat}

Studiul de față, fără a avea pretenții de exhaustivitate, incearcă, pornind de la pixidele din bronz și fier descoperite in anul 2010 cu ocazia cercetărilor arheologice preventive, datorate construcției Autostrăzii Arad-Timișoara, respectiv tronsonul Arad-Seceani, in mormintele 3 și 7 din cadrul necropolei cercetate la Hunedoara Timișană, com. Șagu, jud. Arad, o analiză a pieselor de acesti tip descoperite in mediul sarmatic din Campia Panonică. Autorul analizează piesele de la Hunedoara Timișană, alături de celelate descoperite in complexele funerare din Campia Panonică, intr-un context mai larg și constată că mormintele din care provin aceste pixide sunt ale unor persoane de sex feminin și de copii. Pixidele din M 3 de la Hunedoara Timișană, in corelare cu restul inventarului din mormânt, dar și a mormintelor din preajmă, indică in opinia autorului, o datare a acestuia cel mai probabil cândva in a doua treime/mijlocul - al treilea sfert al sec. III p. Chr. In cea ce privește piesa din M 7 s-a conchis că aceasta a fost utilizată mai curând ca zdrăngănitoare (Pyxidenklappern), avand astfel mai degrabă funcția de pandantiv, mormântul datandu-se candva in intervalul cronologic cuprins intre sfârșitul sec. II p. Chr. și al treilea sfert al sec. III p. Chr.

In urma analizei descoperirilor de astfel piese metalice din mediul sarmatic autorul remarcă că acestea nu sunt des documentate in necropolele sarmatice 
din Campia Panonică și că aria de răspândire a lor se situează cu precădere in bazinul Tisei, fiind reprezentate inclusiv in teritoriul cuprins intre Mureșul Inferior, Tisa și Dunăre. Pe baza procedeului de realizare, decorului și a modului de executare a acestuia autorul ajunge la concluzia că pixidele din bronz din M 3 de la Hunedoara Timișană sunt, probabil, artefacte realizate de un meșter roman, posibil ambulant, care a activat in zona de interacțiune economică din vecinătatea limes-ului.

In final se conchide că in pixidele metalice din mediul sarmatic din Câmpia Panonică se păstrau, la fel ca și in cele din restul lumii sarmatice estice, atât produse cosmetice cat și diferite plante medicinale vindecătoare.

Cuvinte-cheie: pixide, morminte, sarmați, iazigi, Marea Campie Ungară, Banat, Barbaricum

Bârcă, Vitalie. Institute of Archaeology and Art History of Cluj- Napoca, Romania. (http://www.jaha.org.ro).E-mail: vitalie_barca@yahoo.com 